\title{
The yield and cell viability of bovine in vivo recovered embryos in relation to season of flushing
}

\author{
L. Stádník',4, A.V. Makarevich ${ }^{2,3}$, M. Doležalová1, E. Kubovičová2,3, J. Beran¹, Z. Hegedüšová3, \\ J. Ćítek ${ }^{1}$, R. Holásek ${ }^{3}$ and R. Stupka ${ }^{1}$ \\ ${ }^{1}$ Czech University of Life Sciences Prague, Faculty of Agrobiology, Food and Natural Resources, \\ Department of Animal Husbandry, Kamycka 129, 16521 Prague 6 - Suchdol, Czech Republic \\ ${ }^{2}$ Animal Production Research Centre Nitra, 95141 Lužianky near Nitra, Slovak Republic \\ ${ }^{3}$ Institute for Cattle Breeding Ltd. Rapotin, Vyzkumniku 267, 78813 Vikyrovice, Czech Republic
}

KEY WORDS: superovulation, embryo, season, apoptosis, actin cytoskeleton, cows

Received: 28 June 2013

Revised: 22 October 2014

Accepted: 28 November 2014

${ }^{4}$ Corresponding author:

e-mail: stadnik@af.czu.cz

\begin{abstract}
The objective of this study was to evaluate effect of the season on the yield and viability of embryos recovered from superovulated and flushed Holstein cows $(n=56)$. The embryo recovery rate $(E R R, \%)$ was determined as the proportion of totally flushed embryos (TFE, $n$ ) to the number of corpora lutea detected. The embryos were evaluated as transferable (TRANS) or non-transferable and analysed for occurrence of apoptotic cells (T+, TUNELindex) as well as actin cytoskeleton quality (ACG). TFE and ERR were the highest during spring vs summer (149 embryos, $59.6 \%$ vs 20 embryos, $37 \%$; $P<0.001$ ), while they insignificantly differed in autumn ( 57 embryos, $48.3 \%)$. The autumn embryos presented a higher proportion of TRANS $(P<0.05,+10.56 \%$ vs spring; $+18.94 \%$ vs summer). The occurrence of apoptosis in these embryos was lower $(-1.38 \mathrm{~T}+$ cells and $-1.75 \% \mathrm{~T}$-index; $P<0.05)$ and the percentage of the best ACG was higher $(+35 \% ; P<0.05)$. These findings identified autumn as the best season for collection of high-quality bovine embryos.
\end{abstract}

\section{Introduction}

Currently, embryo transfer (ET) represents a major breeding procedure accelerating genetic progress, mainly in cattle breeding (Merton et al., 2003). The number of bovine embryo transfers is showing an increasing tendency globally, although during the last 7-9 years the trend has been declining in the Czech Republic. Deterioration of results documents the need for re-evaluation to ensure optimal management and efficient utilization of all factors (Stádník et al., 2013). The most serious problem in ET is the unreliability of the superovulation reaction (Szabari et al., 2008) characterized by high variability influenced by many internal factors related to the physiological condition of the animal, such as age (Callesen et al., 1996), breed, genetic differences (Kafi and McGowan, 1997), or ovarian size (Hegedüšová and Dufek, 2012). External factors influencing the response to superovulation include nutrition (Berry et al., 2003), subclinical infections (Leroy et al., 2005), lactation (Walsh et al., 2011), repeated superovulation and season (Silva et al., 2009).

According to Wolfenson et al. (2000) and Sartori et al. (2002), season is one of the main factors influencing the superovulation response. There are clear seasonal effects decreasing fertility in the warmer months from June to July (Silva et al., 2009). De Rensis and Scaramuzzi (2003) described 
the decreased intensity of signs, reduced heat duration, increased incidence of anoestrus, and more frequent silent heat under higher temperature, which may also disrupt follicular development and its dominance in Holstein dairy cows (Wolfenson et al., 1995). These facts could be evoked by the significant relationships between cattle body and air temperatures (Němečková et al., 2013) because it is generally known that gamete formation is sensitive to temperature (Badinga et al., 1993).

Metabolic changes have been determined in dairy cows in relation to long-term one-way selection for milk production. This could be caused by the dams' increased sensitivity to the negative impact of temperature differences during the year, i.e. in respect to the season of the year (Chagas et al., 2007). Therefore, repeated evaluation of the effect of season on the reproduction capabilities of dairy cows is necessary.

The most common evaluation of bovine embryo quality involves the proportion of viable embryos (Galli et al., 2004) and transferable or freezable embryos (Ayasan et al., 2011) in relation to basic factors (Cerri et al., 2009; Lee et al., 2012). More detailed analysis in relation to the season has been evaluated rather exceptionally, for example, by the effect of hot or cool season on blastulation and hatching blastocyst formation during subsequent embryo culture (Monty and Racowsky, 1987) or on embryo cell number (Hackbart et al., 2010). Our study brings an innovative application of fluorescent staining techniques for the determination of the embryo cell number, apoptosis and quality of actin cytoskeleton. These characteristics of embryo quality could provide more information about the subsequent developmental potential of embryos compared with basic morphological evaluation. Therefore, the objective of this work was to evaluate the effect of the season of flushing on the yield and cell viability of embryos recovered from superovulated Holstein cows.

\section{Material and methods}

\section{Animals}

A total of 56 Holstein cows calved between March 2009 and August 2011 were included in the experiment: 28, 11 and 17 cows in the first, second, third and subsequent lactations, respectively. The average parity (PAR) of the cows was 1.9. The average breeding value for $\mathrm{kg}$ of milk (BV) of cows was $405.19 \mathrm{~kg}$ with standard deviation 410.18 . Daily milk yield at the beginning of hormonal treatment (MILK), recorded from milk parlour automatic evidence, averaged $29.48 \mathrm{~kg}$ with standard deviation 8.04. All cows selected for observation had no reproductive disorders in the previous period, however, some of them were designated for culling in the near future. This is why days in milk (DIM) varied during the flushing performed, from 40 to 362 days of lactation, with an average of 142 days and standard deviation at the level of 85.9. All cows were classified according to the 5-point scale of body condition score (BCS) by Parker (1989) during the flushing of uterine horns. BCS ranged from 2.0 to 5.0 points, with an average of 2.85 and standard deviation 0.67 . The cows were loose housed in a cubicle straw-bedded barn and fed a total mixed ration consisting of maize and lucerne silage, straw, grass and lucerne hay, brewery draft, bakery waste, molasses, commercial concentrates and mineral supplements. The ingredient composition of the diet corresponded to the level of the daily milk yield and feeding rations were completely balanced for energy, protein, fat, as well as mineral and vitamin content. The feeding rations consisted of the same components throughout all of the seasons during the experiment.

\section{Embryo recovery and evaluation}

The oestrus of the cows was synchronized by injection of a $\mathrm{PGF}_{\text {2alfa }}$ analogue - Oestrophan (Bioveta a.s., Ivanovice na Hane, Czech Republic) during the spring (April to May; $\mathrm{n}=27$ ), summer (June to August; $n=10$ ) and autumn (September to November; $\mathrm{n}=19$ ). The cows were superovulated by application of porcine pituitary gonadotropin (Pluset $^{\mathbb{B}}$ FSHp-LHp, Laboratorios Callier, Barcelona, Spain) twice daily for 5 days at 8.00 and $20.00 \mathrm{~h}$ (given in a decreasing dose; starting with doses of 150 IU FSH +150 IU LH in the morning on day 11 to $50 \mathrm{IU}$ FSH+50 IU LH in the evening on day 15 of the oestrous cycle). On day 13, Oestrophan was administered for luteolysis. Insemination was performed 4 times by one AI technician with frozen-thawed AI doses of one sire at 12-h intervals starting $12 \mathrm{~h}$ after standing oestrous detection. Embryo recovery was performed on the $6^{\text {th }}$ or $7^{\text {th }}$ day after the $1^{\text {st }}$ insemination by a standard non-surgical technique to flush out the uterine horns. The number of corpora lutea $(\mathrm{CL})$ on both ovaries was counted and recorded by one operator during the pre-flushing examination. Uterine flushing was performed with a complete flush solution (Bioniche, Belleville, Ontario, Canada) using a silicone two-way Foley catheter (Minitüb GmbH, Tiefenbach, Germany). Flushed embryos were transferred to the holding medium, 
phosphate buffered solution (PBS) with $20 \%$ foetal calf serum (FCS, Gibco BRL), and assessed using a stereomicroscope. The total number of flushed embryos (TFE) was counted and the embryo recovery rate (ERR) in percent was determined in relation to the number of CL detected. Subsequently, the embryos were evaluated according to their stage of development as transferable (i.e. morulas, blastocysts - TTRANS) and non-transferable (i.e. unfertilized oocytes and fragmented embryos). Thereafter, the TRANS embryos were analysed for apoptotic cell occurrence ( $\mathrm{T}+$, TUNEL-index), embryo cell number $(\mathrm{ECN})$, and grades of actin cytoskeleton quality (ACG).

\section{Analysis of embryos for TUNEL, embryo cell number and actin cytoskeleton}

Due to the very low number of embryos flushed during the summer, the detailed quality assessment of embryos was performed only in embryos flushed in the spring $(\mathrm{n}=35)$ and autumn $(\mathrm{n}=32)$. These embryos were washed three times for $5 \mathrm{~min}$ in PBSPVP washing solution (PBS with $4 \mathrm{mg} / \mathrm{ml}$ polyvinylpyrrolidone; Sigma-Aldrich Chemie, Steinheim, Germany). Then the embryos were fixed in 3.7\% neutrally buffered formalin (Fluka, Buchs, Switzerland) for $10 \mathrm{~min}$. Permeabilization was done by $1 \mathrm{~h}$ incubation of embryos in $0.5 \%$ Triton X-100 in PBS. Afterward, the embryos were processed for apoptosis detection using In situ Cell Death Detection kits (Roche Slovakia Ltd., Bratislava, Slovak Republic) according to the product manual. Briefly, fixed and permeabilized embryos were incubated at $37^{\circ} \mathrm{C}$ in the TUNEL-detecting solution, consisting of fluorescence-labelled nucleotides (dUTP-FITC, $37 \mu \mathrm{l}$ ) and terminal transferase (TdT, $3 \mu \mathrm{l})$, at $37^{\circ} \mathrm{C}$ for $1 \mathrm{~h}$. Following this incubation the TUNEL-reaction was stopped by washing the embryos three times in PBS-PVP solution. For labelling of actin filaments, the embryos were put into a solution of phalloidineTRITC conjugate, which is a component of the Actin Cytoskeleton and Focal Adhesion Staining Kit (Chemicon International, Temecula, CA, USA) for $45 \mathrm{~min}$. Thereafter, the embryos were washed three times in PBS-PVP solution, transferred onto a coverslip and covered with $5 \mu$ of Vectashield anti-fade mounting medium containing DAPI stain (Vector Laboratories, Burlingame, CA, USA). The coverslip was attached to the microslide using nail polish. All treatments were performed at ambient temperature. The samples were stored at $-20^{\circ} \mathrm{C}$ until fluorescence analysis. The TUNEL-index was determined on the basis of the proportion of TUNEL-positive nuclei (green fluorescence) to total embryo cell number
(DAPI-stained nuclei), which was counted under a Leica fluorescent microscope (Leica Microsystems, Germany) using specific wave-length filters. The actin cytoskeleton was classified according to Tharasanit et al. (2005) on the basis of the appearance of actin filaments in horse embryos, with our adaptation to bovine embryos, as belonging to 3 grades (Makarevich et al., 2012). Grade I (best quality) - sharply stained actin filaments of reticular shape in cell borders; grade II (fair quality) - blastomeres with less pronounced actin filaments without sharp borders on membranes; grade III (poor quality) - large areas lacking actin staining or visible actin largely aggregated into intracytoplasmic clumps.

\section{Statistical evaluation}

The experiment was performed in 6 replications. Variability of PARITY, DIM, BV, MILK and BCS among individual seasons was tested by oneway ANOVA at the level of statistical significance $P<0.05$. One-way ANOVA and the Tukey-test were used to analyse differences in the TUNELindex between groups. Since the TUNEL-index was a normally distributed variable, log-transformation of original values was done. The hypothesis of normality was rejected for 'TUNEL cells per embryo' and for 'Embryo cell number'. For these two variables the log-transformation of original values was used. The incidence of fragmented embryos was analysed using the Chi-square test. The treatment effect on actin cytoskeleton quality was tested using the Mann-Whitney U test. All calculations were performed using the SAS software package (SAS, 2001).

\section{Results}

The basic results of embryo flushing according to the season of the experiments performed on Holstein cows are documented in Table 1. The highest number of dams responded to synchronization and superovulation during the spring, the lowest, during the summer. Three cows did not respond to hormonal treatment in the spring, 2 dams in the summer and 2 in the autumn. The success rate of superovulation was different during the particular seasons. In the spring, $88.89 \%$ of the cows positively responded to superovulation, only $80.00 \%$ in the summer and the highest proportion was recorded in the autumn, $89.47 \%$. The PAR of treated dams averaged in the groups from 1.5 to 2.2, therefore differences among them ranged from 0.1 to 0.7 . The groups of dairy cows were characterized by a BV from 315.88 to 608.37 with differences from 69.29 to 292.49 . 
Table 1. Basic characteristics of superovulated dairy cows according to season of flushing

\begin{tabular}{|c|c|c|c|c|c|c|}
\hline Season & $\begin{array}{l}\text { COWS, } \\
n\end{array}$ & $\begin{array}{l}\text { RESP, } \\
\%\end{array}$ & $\begin{array}{l}\text { PARITY, } \\
\mathrm{n}\end{array}$ & $\begin{array}{l}\mathrm{BV}, \\
\mathrm{kg}\end{array}$ & $\begin{array}{l}\text { MILK, DIM, } \\
\mathrm{kg} \text { day }\end{array}$ & $\begin{array}{l}\text { BCS, } \\
\text { point }\end{array}$ \\
\hline Spring & 27 & 88.89 & 2.2 & 385.17 & 29.76146 & 2.76 \\
\hline Summer & 10 & 80.00 & 1.5 & 315.88 & 29.62117 & 2.57 \\
\hline Autumn & 19 & 89.47 & 1.6 & 608.37 & 28.89147 & 3.13 \\
\hline
\end{tabular}

Spring - April to May, Summer - June to August, Autumn - September to November; RESP - proportion of cows positively responded to superovulation, PARITY - ranking of lactation, BV - breeding value for $\mathrm{kg}$ of milk, MILK - daily milk yield on the day of superovulation start, DIM - number of days in milk, BCS - body condition score of embryo donors

The MILK of dams was completely comparable among the groups because the differences ranged only from 0.14 to $0.87 \mathrm{~kg}$ of milk. Average DIM ranged from 117 to 147 days in individual seasons, thus the differences were within 30 days. Individual groups of dairy cows slightly differed in the level of BCS, with the highest BCS being recorded in cows treated during the autumn ( +0.37 to +0.56 points), while the lowest, in the summer ( -0.19 to -0.56 points). None of these differences were statistically significant.

As Table 2 documents, the number of CL was insignificantly different among seasons. A total of $250 \mathrm{CL}$ was recorded in cows flushed during the spring, $118 \mathrm{CL}$ during the autumn, and only $54 \mathrm{CL}$ during the summer. The total number of flushed embryos (TFE) and embryo recovery rate (ERR) values showed similar trends and were significantly $(P<0.001)$ highest during the spring compared with the summer (TFE 149 embryos, ERR 59.60\% vs TFE 20 embryos, ERR 37.04\%), whereas they were not significantly different during the autumn (TFE 57 embryos, ERR 48.3\%). Although the TFE yielded during the autumn was at a moderate level (57 embryos), the proportion of transferable embryos was significantly higher $(+10.56 \%$ compared with the spring, respectively, $+18.94 \%$ compared with the summer; both $P<0.05$ ).

Table 2. Number of corpora lutea, totally flushed embryo, embryo recovery rate and proportion of transferable embryos in relation to season

\begin{tabular}{llrllll}
\hline \multirow{2}{*}{ Season } & COWS, & $\mathrm{CL}$, & TFE, & ERR, & \multicolumn{2}{c}{ TRANS } \\
\cline { 6 - 8 } & $\mathrm{n}$ & \multicolumn{1}{c}{$\mathrm{n}$} & \multicolumn{1}{c}{$\mathrm{n}$} & \multicolumn{1}{l}{$\%$} & $\mathrm{n}$ & $\%$ \\
\hline Spring & 27 & 250 & 149 & $59.60^{\mathrm{a}, \mathrm{A}}$ & $87^{\mathrm{c}}$ & $58.38^{\mathrm{c}}$ \\
Summer & 10 & 54 & 20 & $37.04^{\mathrm{b}, \mathrm{B}}$ & $12^{\mathrm{c}}$ & $60.00^{\mathrm{c}}$ \\
Autumn & 19 & 118 & 57 & 48.30 & $45^{\mathrm{d}}$ & $78.94^{\mathrm{d}}$
\end{tabular}

Spring - April to May, Summer - June to August, Autumn - September to November; $\mathrm{CL}$ - number of corpora lutea detected at pre-flushing examination, TFE - number of totally flushed embryos, ERR - embryo recovery rate, TRANS - embryos suitable for transfer; ${ }^{A B}$, abc means with different superscripts within a column are significantly different at $P \leq 0.01$ or $P \leq 0.05$, respectively
Table 3. The influence of season on the incidence of fragmented embryos

\begin{tabular}{llll}
\hline Season & TFE, & FRAG \\
\cline { 3 - 4 } & $\mathrm{n}$ & 22 & $\%$ \\
\hline Spring & 80 & 12 & 27.50 \\
Autumn & 57 & 21.05 \\
\hline
\end{tabular}

Spring - April to May, Autumn - September to November; TFE number of totally flushed embryos, FRAG - number and proportion of fragmented to totally flushed embryos

For more detailed evaluation, some of the embryos were analysed for incidence of cytoplasmic fragmentation in particular seasons (Table 3). A slightly $(P>0.05)$ lower number of fragmented embryos $(-10$ embryos) as well as fragmentation rate $(-6.45 \%)$ was found in the autumn compared with the spring.

Table 4 shows the significant $(P<0.05)$ effect of flushing season on the quality of embryos, expressed as embryo cell number (ECN), number of apoptotic (TUNEL-positive) nuclei per embryo $(\mathrm{T}+)$, as well as TUNEL index (T-index) and distribution of embryos according to the quality grades of the actin cytoskeleton (ACG). The results demonstrated that compared with the embryos obtained in the spring $(n=35)$, the quality of the autumn embryos $(n=32)$ was higher. Although a smaller total number of embryos was obtained during this season, $(-15.17$ per embryo), these embryos demonstrated a lower number $(-1.33$ cell per embryo, $P<0.05)$ of cells with apoptotic (TUNEL-positive) nuclei. The TUNEL index was lower by even $1.75 \%(P<0.05)$ with a significantly lower standard error of mean during the autumn. Similar results were found in relation to the distribution of embryos into individual actin cytoskeleton grades (I-III). Embryos collected during the autumn contained a significantly $(P<0.05)$ higher percentage of grade I (best quality actin net) embryos (by 35\%) and lower percentage of grades II and III (fair and poor quality actin cytoskeleton) embryos (by $10 \%$ and $25 \%$ ).

Table 4. Influence of season on embryo cell number, apoptosis incidence, and actin cytoskeleton quality

\begin{tabular}{|c|c|c|c|c|c|c|}
\hline \multirow{2}{*}{ Season } & \multirow{2}{*}{$\mathrm{ECN}, \mathrm{n}$} & \multicolumn{2}{|c|}{ Apoptosis incidence } & \multicolumn{3}{|c|}{ ACG, $\%$} \\
\hline & & $T+, n$ & T-index, \% & I & II & III \\
\hline $\begin{array}{l}\text { Spring } \\
\qquad(\mathrm{n}=35)\end{array}$ & $82.60 \pm 6.44^{a}$ & $3.88 \pm 0.75^{\mathrm{a}}$ & $4.74 \pm 0.99^{a}$ & $50^{\mathrm{a}}$ & $20^{\mathrm{a}}$ & $30^{\mathrm{a}}$ \\
\hline $\begin{array}{l}\text { Autumn } \\
\qquad(\mathrm{n}=32)\end{array}$ & $67.43 \pm 4.16^{b}$ & $2.50 \pm 0.30^{b}$ & $2.99 \pm 0.31^{b}$ & $85^{b}$ & $10^{b}$ & $5^{b}$ \\
\hline
\end{tabular}

Spring - April to May, Autumn - September to November; ECN - total embryo cells number (the mean $\pm \mathrm{SEM}$ ); $\mathrm{T}+-$ the number (the mean \pm SEM) and T-index - the proportion (the mean \pm SEM) of TUNEL positive cells per embryo; ACG - distribution of embryos according to actin cytoskeleton grades; ${ }^{\text {ab }}$ means with different superscripts within a row are significantly different at $P \leq 0.05$ 


\section{Discussion}

Embryo transfer (ET) can be used in animal breeding (Duszewska et al., 2012), mainly as a part of a cattle breeding system (Merton et al., 2003). Stádník et al. (2013) reported a growing trend of ETs performed worldwide, however, significantly reduced ET cycles have been recorded in the Czech Republic. This declining trend is a motive for its detailed analysis and effectivity evaluation. The most serious problem with ET is unreliability of the potential response to superovulation (Szabari et al., 2008), correlating with the known fact that fertility is a multi-factorial trait and its level is affected by many factors (Walsh et al., 2011). At least, we can exclude an interbreed effect, which can occur in superovulation responses (Baruselli et al., 2006), because only Holstein dairy cows were evaluated in our experiment.

One factor probably influencing reproduction results could be the age of dams. Zavadilová and Štípková (2013) described differences in reproduction of Holstein primiparous cows in relation to age at first calving. Grimard et al. (2013) reported the effect of parity on plasma IGF-I concentrations, number of follicles aspirated per session and fertility traits, but not on the number of oocytes recovered per session or on their quality. They found significantly better reproduction traits in primiparous compared with multiparous cows. According to this, parity needs to be considered when evaluating reproduction results. The average parity of dams observed in our experiments only slightly (from \pm 0.1 to 0.7 lactation) differed among individual seasons, which indicates that the effect of parity was insignificant.

The genotype of dairy cows was proved to exert a significant effect on reproduction results (Stádník and Louda, 1999). Zink et al. (2012) determined the genetic parameters for female fertility in relation to the accuracy of the selection index under different scenarios, when Šafus et al. (2005) stated the necessity of incorporating breeding values for reproduction traits into the Czech selection indexes for the Holstein breed based on the BV for milk production. The average $\mathrm{BV}$ in dairy cows flushed during individual seasons fluctuated only within the range of 69-293 kg. If, on the national level, the BV in Czech Holstein cows ranges from 620 to $2615 \mathrm{~kg}$, with a standard deviation of $500.8 \mathrm{~kg}$ (Motyčka et al., 2012), it can be assumed that differences up to $293 \mathrm{~kg}$ (only $58.5 \%$ of the population standard deviation) could not affect the evaluated traits of embryo yield and quality.
The quantity and quality of the feed ration is another possible effect (Louda and Stádník, 2000), because feeding management influences MILK and $\mathrm{BCS}$, which in turn, influence reproductive performance (Brun-Lafleur et al., 2013). Numerous experiments have pointed to the effect of feed intake restriction on growth rate and size of the ovulatory follicle and to the negative effect of excessive nutritional status on the quality (worse) of oocytes and embryos (Yaakub et al., 1999; Armstrong et al., 2001). On the other hand, Aparicio-Cecilio et al. (2012) who tested addition of selected activators of energy metabolism on dairy cow ovarian activity, reported that it did not affect the serum lipid profile or ovarian activity. The totally mixed ration system of feeding was used during the whole period of our observation and no fresh components (green grass) were fed within the diet. The feed ration consisted of the same components through all of the seasons during the experiments. The feed rations used in our experiments correlated with the current daily milk yield and were balanced for energy, protein, fat, as well as mineral and vitamin content. This fact is confirmed by very low and insignificant differences in MILK and BCS, therefore, we assume that the type of nutrition did not affect the evaluated parameters of embryo yield and quality in our study.

Leroy et al. (2008) associated the effect of different DIM with the negative energy balance (NEB) of high-yielding dairy cows occurring in the first 5-10 weeks post partum. The average DIM of groups observed during our experiments ranged from 117 to 147 and differed only up to 30 days. Referring to the common duration of the NEB period, the dairy cows had already probably overcome this lactation phase before the beginning of hormonal treatment and the effect of this factor was insignificant as well.

The health status of dairy cows could be another factor affecting their reproduction abilities. Vacek et al. (2007) revealed significant relationships between the incidence of health disorders and reproduction traits. Similarly, Rajmon et al. (2012) studied mutual relationships between ovarian follicle growth and cyst occurrence in Holstein cows in the Czech Republic. The dams entered into our experiments, however, were pre-selected according to their good health status and previous periods without reproductive disorders.

As has been reported, cow conception rates may be influenced by the quality of AI doses (Beran et al., 2012) and quality of AI technicians' service (Walsh et al., 2011). In our work, only AI doses obtained from one sire were used and they were applied by one (the 
same) AI technician; this fact eliminates the possible influence of the sire's individuality and service quality on the results of the performed AI.

Basing on the above, the effect of season of the year was the main factor that could have influenced the results of our experiments. Previous studies documented that reproductive performance of dairy (Sartori et al., 2002) and beef (Wolfenson et al., 2000) cattle can be influenced by season of the year. It is reduced during the hot summer months, which can be the result of changes in follicular growth, corpus luteum function, expression of oestrous behaviour, superovulatory response, quality of embryos and fertility (Armstrong et al., 2001; Webb et al., 2004; Barati et al., 2006). Alberghina et al. (2013) detected significant effects of ambient temperature and relative humidity on selected blood metabolites related to the functional metabolism of dairy cows. Therefore, it is possible that the differences in temperature among the seasons of the year can affect embryo quality, because a negative effect of higher temperatures was determined in relation to subsequent follicular development and dominance (Wolfenson et al., 1995), dominant follicle lifespan (Lew et al., 1993), as well as conception rate of dairy cows (Silva et al., 2009).

Our findings corroborate these statements, because the embryo recovery rate and proportion of transferable embryos achieved the lowest level during the summer. Similarly, the proportion of cows that positively responded to superovulation was the lowest in the summer. These facts can be explained by compromised ovarian follicular dynamics (Badinga et al., 1993), increased ability of the dominant follicle to exert dominance (Wolfenson et al., 1995), or induced follicular co-dominance (Sartori et al., 2010) under higher air temperature. Lew et al. (1993) reported that the high temperatures could evoke heat stress affecting the enzymatic cascade of steroids in the cells of the dominant follicle, and recent findings indicate that even oocytes are sensitive to higher temperature. Production of embryos by superovulation is also reduced, because a high surrounding temperature affects the embryo, especially at the initial stages of development (Badinga et al., 1993). This may partly explain the significantly higher production of low-quality embryos and lowest share of transferable embryos obtained during the summer.

Very little information about the cell quality of embryos obtained from dairy cows and evaluated in relation to the season of the year is available. The effect of season has been determined mainly in relation to the conception rate of dairy cows after classic insemination (Stádník et al., 2002) or recipients following embryo transfer (Hasler, 2001). Our observation brings new and innovative results about the effect of season on the proportion of transferable embryos, as well as their quality, analysed using such invasive techniques as fluorescent staining for embryo cell number, apoptosis and quality of the actin cytoskeleton.

In general, these experiments confirmed an effect of season on the yield and quality of bovine in vivo-recovered embryos. A significantly lower embryo yield, as well as rate of transferable embryos, was found during the summer months. The highest embryo yield was recorded during the spring, while the transferable rate, in the autumn. Moreover, dairy cows flushed during the autumn produced fewer fragmented embryos and a lower percentage of apoptotic cells. Also the highest quality of the actin cytoskeleton was detected in the autumn embryos. These findings explain the highest $(P<0.05)$ share of transferable embryos collected in the autumn, and show that the autumn as the best season for embryo transfer in cattle (Kubovičová et al., 2013).

ET is a biotechnology offering high genetic gain achievement, especially in relation to possible combination with application of genomic technologies. However, the individual steps of ET represent high financial demands; therefore it is very important to increase its effectiveness in general. Determination of the most suitable season of the year can help reach this goal. Our results indicate that the best season for collection of high quality transferable bovine embryos is the autumn. Therefore, we can recommend organizing embryo recovery from high production dairy cow herds during this time of year.

\section{Acknowledgements}

The study was supported by the ' $\mathrm{S}$ ' Grant of the MŠMT ČR, the NAZV QI91A061 in the Czech Republic and the APVV-0137-10 Grant in the Slovak Republic. We thank Mrs. Lois Russell for editorial help with this manuscript.

\section{References}

Alberghina D., Piccione G., Casella S., Panzera M., Morgante M., Gianesella M., 2013. The effect of season on some blood metabolites and haptoglobin in dairy cows during postpartum period. Arch. Tierzucht 56, 354-359, doi: 10.7482/0003-943856-035

Aparicio-Cecilio A., Bouda J., Salgado-Hernandez E.G., Nunez-Ochoa L., Castillo-Mata D.A., Gutierrez-Chavez A., 2012. Effect of 2-methyl-2-phenoxy propionic acid on serum lipid profile and ovarian activity in dairy cows. Czech J. Anim. Sci. 57, 550-556

Armstrong D.G., McEvoy T.G., Baxter G., Robinson J.J., Hogg C.O., Woad K.J., Webb R., Sinclair K.D., 2001. Effect of dietary energy and protein on bovine follicular dynamics and embryo production in vitro: Associations with the ovarian insulin-like growth factor system. Biol. Reprod. 64, 1624-1632 
Ayasan T., Hizli H., Camlidag A., Kara U., Gok K., Karakozak E., Coban S., Multu H., Kilicalp N., Segmenoglu M.S., 2011. Determination of relationship between milk production and the quality of embryo of donor cows. Indian J. Anim. Sci. 81, 912-914

Badinga L., Thatcher W.W., Diaz T., Drost M., Wolfenson D., 1993. Effect of environmental heat stress on follicular development and steroidogenesis in lactating Holstein cows. Theriogenology $39,797-810$

Barati F., Niasari-Naslaji A., Bolourchi A., Sarhaddi F., Razavi K., Naghzali E., Thatcher W.W., 2006. Superovulatory response of Sistani cattle to three different doses of FSH during winter and summer. Theriogenology 66, 1149-1155

Baruselli P.S., de Sa Filho M.F., Martins C.M., Nasser L.F., Nogueira M.F.G., Barros C.M., Bo G.A., 2006. Superovulation and embryo transfer in Bos indicus cattle. Theriogenology 65, 77-88

Beran J., Stádník L., Bezdíček J., Louda F., Čítek J., Ducháček J., 2012. Effect of sire and extender on sperm motility and share of live or dead sperm in bulls' fresh ejaculate and in Al doses after thawing. Arch. Tierzuht 55, 207-218

Berry D.P., Buckley F., Dillon P., Evans R.D., Rath M., Veerkamp R.F., 2003. Genetic relationship among body condition score, body weight, milk yield, and fertility in dairy cows. J. Dairy Sci. 86 , 2193-2204

Brun-Lafleur L., Cutullic E., Faverdin P., Delaby L., Disenhaus C., 2013. An individual reproduction model sensitive to milk yield and body condition in Holstein dairy cows. Animal 7, 1332-1343, available on CJ02013, doi: 10.1017/S1751731113000335

Callesen H., Liboriussen T., Greve T., 1996. Practical aspects of multiple ovulation - embryo transfer in cattle. Anim. Reprod. Sci. 42, 215-226

Cerri R.L.A., Juchem S.O., Chebel R.C., Rutigliano H.M., Bruno R.G.S., Galvão K.N., Thatcher W.W., Santos J.E.P., 2009. Effect of fat source differing in fatty acid profile on metabolic parameters, fertilization, and embryo quality in high-producing dairy cows. J. Dairy Sci. 92, 1520-1531

Chagas L.M., Bass J.J., Blache D. et al., 2007. New perspectives on the roles of nutrition and metabolic priorities in the subfertility of high-producing dairy cows. J. Dairy Sci. 90, 4022-4032

De Rensis F., Scaramuzzi R.J., 2003. Heat stress and seasonal effects on reproduction in the dairy cow - a review. Theriogenology 60, 1139-1151

Duszewska A.M., Rapała Ł., Trzeciak P., Dabrowski S., Piliszek A., 2012. Obtaining farm animal embryos in vitro. J. Anim. Feed Sci. 21, 217-233

Galli C., Duchi R., Crotti G., Turini P., Ponderato N., Colleoni S., Lagutina I., Lazzari G., 2004. Production and quality of bovine oocytes and embryos. Vet. Res. Commun. 28, 121-126

Grimard B., Marquant-Leguienne B., Remy D., Richard C., Nuttinck F., Humblo, P., Ponter A.A., 2013. Postpartum variations of plasma igf and igfbps, oocyte production and quality in dairy cows: Relationships with parity and subsequent fertility. Reprod. Domest. Anim. 48, 183-194

Hackbart K.S., Ferreira R.M., Dietsche A.A., Socha M.T., Shaver R.D., Wiltbank M.C., Fricke P.M., 2010. Effect of dietary organic zinc, manganese, copper, and cobalt supplementation on milk production, follicular growth, embryo quality, and tissue mineral concentrations in dairy cows. J. Anim. Sci. 88, 3856-3870

Hasler J.F., 2001. Factors affecting frozen and fresh embryo transfer pregnancy rates in cattle. Theriogenology $56,1401-1415$

Hegedüšová Z., Dufek A., 2012. Effect of size of ova and number of corpus luteum on the amount of recovered embryos and embryo quality (in Czech). Cattle Res. 2, 51-57
Kafi M., McGowan M.R., 1997. Factors associated with variation in the superovulatory response of cattle. Anim. Reprod. Sci. 2, 137-157

Kubovičová E., Makarevich A., Stádník L., Holásek R., Hegedušová Z., 2013. Effect of body condition and season on the yield and quality of cattle embryos. J. Microbiol. Biotech. Food Sci. 2, Special Issue on BQRMF, 1426-1435

Lee W.Y., Song K.Y., Lim K.T., Lee S.J., Lee B.Ch., Jang G., 2012. Influence of Factors during Superovulation on Embryo Production in Korean Holstein Cattle. J. Vet. Med. Sci. 74, 167-174

Leroy J.L.M.R., Vanholder T., Mateusen B., Christophe A., Opsomer G., de KruifA., Genicot G., Van Soom A., 2005. Non-esterified fatty acids in follicular fluid of dairy cows and their effect on developmental capacity of bovine oocytes in vitro. Reproduction 130, 485-495

Leroy J.L.M.R., Van Soom A., Opsomer G., Goovaerts I.G.F., Bols P.E.J., 2008. Reduced fertility in high-yielding dairy cows: Are the oocyte and embryo in danger? Part II. Reprod. Domest. Anim. 43, 623-632

Lew D.J., Marini N.J., Reed S.I., 1993. A suppressor of cln3 for size control. Cell 72, 488-489

Louda F., Stádník L., 2000. The effect of different levels of nutrition on hormone and ovulation activity in ruminants (in Czech). Czech J. Anim. Sci. 45, 553-556

Makarevich A.V., Kubovičová E., Hegedűšová Z., Pivko J., Louda F., 2012. Post-thaw culture in presence of insulin-like growth factor I improves the quality of cattle cryopreserved embryos. Zygote 20, 97-102

Merton J.S., de Roos A.P.W., Mullaart E., de Ruigh L., Kaal L., Vos P.L.A., Dieleman S.J., 2003. Factors affecting oocyte quality and quantity in commercial application of embryo technologies in the cattle breeding industry. Theriogenology 59, 553-597

Monty Jr. D.E., Racowsky C., 1987. In vitro evaluation of early embryo viability and development in summer heat-stressed, superovulated dairy cows. Theriogenology 28, 451-465

Motyčka J., Lipovský D., Vondrášek L., 2012. Annual Report 2011 of Holstein Cattle Breeders Association of the Czech Republic [online]. Holstein Cattle Breeders Association of the Czech Republic, Accesible from: <http://www.holstein.cz/index.php/ Annual-reports>, [cit. 2013-06-09]

Němečková D., Knižková I., Kunc P., Stádník L., 2013. The effect of the design of housing systems for calves on the microclimatic conditions of the rearing environment. Arch. Tierzucht 56, 509-517, doi: 10.7482/0003-9438-56-049

Parker R., 1989. Using Body Condition Scoring in Dairy Herd Management [online]. Ministry of Agriculture. Food \& Rural Affairs Ontario. Queen's Printer for Ontario. Factsheet. Publication Date 01/89, Last Reviewed 07/12. Accesible from: <http:// www.omafra.gov.on.ca/english/livestock/dairy/facts/94-053. htm\#top>, [cit. 2013-06-09]

Rajmon R., Šichtař J., Vostrý L., Řehák D., 2012. Ovarian follicle growth dynamics during the postpartum period in Holstein cows and effects of contemporary cyst occurrence. Czech J. Anim. Sci. 57, 562-572

Sartori R., Bastos M.R., Wiltbank M.C., 2010. Factors affecting fertilisation and early embryo quality in single and superovulated dairy cattle. Reprod. Fert. Develop. 22, 151-158

Sartori R., Sartor-Bergfelt R., Mertens S.A., Guenther J.N., Parrish J.J., Witbank M.C., 2002. Fertilization and early embryonic development in heifers and lactating cows in summer and lactating and dry cows in winter. J. Dairy Sci. 85, 2803-2812

SAS, 2001. Release 8.02 (TS2MO) of the SAS® System for Microsoft $₫$ Windows $\circledR^{\circledR}$. SAS Institute Inc. Cary, NC

Silva J.C.C., Alvarez R.H., Zanenga C.A., Pereira G.T., 2009. Factors affecting embryo production in superovulated Nelore cattle. Anim. Reprod. 6, 440-445 
Stádník L., Hegedüšová Z., Makarevich A., Kubovičová E., Louda F., Beran J., Nejdlová M., 2013. Increasing of embryo transfer effectiveness in Holstein cows using their body condition evaluation (in Czech). $1^{\text {st } E d i t i o n, ~ C ̌ Z U ~ v ~ P r a z e, ~ C o p y ~ C e n t r u m ~}$ Powerprint, Praha, pp. 35

Stádník L., Louda F., 1999. The effect of genetic parameters of sire in France on the performance and reproduction of daughters imported to the Czech Republic and calving here (in Czech). Czech J. Anim. Sci. 44, 433-439

Stádník L., Louda F., Ježková A., 2002. The effect of selected factors at insemination on reproduction of Holstein cows. Czech J. Anim. Sci. 47, 169-175

Szabari M., Pinnyey S., Boros, N., Sebestyén J., Retter Y., 2008. Some factors affect of embryo-flushing in dairy cattle. Acta Agr. Kapos. 12, 113-120

Šafus P., Štípková M., Stádník L., Přibyl J., Čermák V., 2005. Subindexes for bulls of Holstein breed in the Czech Republic. Czech J. Anim. Sci. 50, 254-265

Tharasanit T., Colenbrander B., Stout T.A.E., 2005. Effect of cryopreservation on the cellular integrity of equine embryos. Reproduction 129, 789-798

Vacek M., Stádník L., Štípková M., 2007. Relationships between the incidence of health disorders and the reproduction traits of Holstein cows in the Czech Republic. Czech J. Anim. Sci. 52, 227-235
Walsh S.W., Williams E.J., Evans A.C.O., 2011. A review of the causes of poor fertility in high milk producing dairy cows. Anim. Reprod. Sci. 123, 127-138

Webb R., Garnsworthy P.C., Gong J.C., Armstrong D.G., 2004. Control of follicular growth: Local interactions and nutritional influences. J. Anim. Sci. 82, E63-E74

Wolfenson D., Roth Z., Meidan R., 2000. Impaired reproduction in heatstressed cattle: basic and applied aspects. Anim. Reprod. Sci. 60/61, 535-547

Wolfenson D., Thatcher W.W., Badinga L., Savio J.D., Meidan R., Lew B.J., 1995. The effect of heat stress on follicular development during the estrous cycle dairy cattle. Biol. Reprod. 52, 1106-1113

Yaakub H., O'Callaghan D., Boland M.P., 1999. Effect of type and quantity of concentrates on superovulation and embryo yield in beef heifers. Theriogenology 51, 1259-1266

Zavadilová L., Štípková M., 2013. Effect of age at first calving on longevity and fertility traits for Holstein cattle. Czech J. Anim. Sci. 58, 47-57

Zink V., Lassen J., Štípková M., 2012. Genetic parameters for female fertility and milk production traits in first-parity Czech Holstein cows. Czech J. Anim. Sci. 57, 108-114 